\title{
Occurrence of Secondary Metabolites and Free Radical Scavenging Ability towards Better Adaptability of Some Mangrove Species in Elevated Salinity of Indian Sundarbans
}

\author{
Nirjhar Dasgupta ${ }^{1}$, Paramita Nandy ${ }^{2}$, Chandan Sengupta $^{3}$ and Sauren Das ${ }^{1 *}$ \\ ${ }^{1}$ Agricultural and Ecological Research Unit Indian Statistical Institute \\ 203, Barrackpore Trunk Road Kolkata - 700108 \\ ${ }^{2}$ Department of Botany Sister Nibedita Government General Degree College for \\ Girls 20B, Judges Court Rd, Alipore, Kolkata - 700027. \\ ${ }^{3}$ Department of Botany University of Kalyani, Kalyani, Nadia - 741235
}

\section{ABSTRACT}

Mangrove, a specialized group of plant communities, provide immense ecological and protective benefits to the coastal areas of the tropical and subtropical world where they thrive. Demographic obligation and climatic hostilities have massively altered their vegetation pattern and, even ruined some key species to large extent. The present study aims to consider Reactive Oxygen Species (ROS) scavenging skills in some degrading mangrove taxa of Indian Sundarbans (Xylocarpus granatum and Heritiera fomes) compared with some opulently growing ones (Excoecaria agallocha, Bruguiera gymnorrhiza and Phoenix paludosa) in increasing salinity gradient, in relation to their sustainability. Non-enzymatic antioxidants (secondary metabolites) Proanthocyanidin and Tannin were estimated and Free radical scavenging ability was evaluated by Singlet Oxygen Scavenging Activity Assay, Reducing power assay, effects on Peroxynitrite, Nitric Oxide Radical Scavenging, Hydrogen Peroxide Scavenging Activity Assay, Reaction with Hypochlorous Acid, Superoxide Radical Scavenging Activity Assay and Hydroxyl Radical Scavenging Activity. Relatively higher occurrence of secondary metabolites and improved antioxidant ability were recorded in $E$. agallocha, B. gymnorrhiza and P. paludosa; than the other two plants $X$. granatum and $H$. fomes; where the trend showed a decline in the ROS scavenging after a certain increase in salinity. Strong positive correlation of both secondary metabolites and radical scavenging ability with salinity pose the three stable taxa more viable in the higher salty environment of the Indian Sundarbans. But relatively less ROS scavenging ability in more saline zones, may be the potential reason for the unfavorable existence of the two red listed plants, which would ultimately lead to gradual natural extinction of them from the Indian Sundarbans.

Keywords: Antioxidant, free radical scavenging, mangroves, Sundarbans, Sustainability

Correspondence: Sauren Das Address: Agricultural and Ecological Research Unit Indian Statistical Institute 203, Barrackpore Trunk Road Kolkata-700108; E-mail: sauren@isical.ac.in

DOI: $10.32945 /$ atr3912.2017 


\section{INTRODUCTION}

Shorelines of the tropical and subtropical world are marked with mangrove vegetation. The coastal environments as well as the habitant privilege the enormous productive and protective abilities of mangrove ecosystem, the estimated commercial assessment of which is approximately US $\$ 186$ million yearly (FAO 2007). Mangrove forests across the globe are being exploited by various natural phenomenon and anthropogenic compulsions (Giri et al 2011). Total coverage of mangrove forest worldwide is estimated at 15.6 million hectares as of 2010, which is down from 1990 estimate of 16.1 million hectares (FAO 2010). This is happening when it is evident that mangroves provide front line defense from sea rainstorms and coastline floods (Spalding et al 2014, Marois \& Mitsch 2015).

Sundarbans mangrove forest in the Indian subcontinent has the highest species richness in the world. The Indian Sundarbans, situated between $21^{\circ} 32^{\prime}-21^{\circ} 55^{\prime} \mathrm{N}$ latitude and $88^{\circ} 42^{\prime}-89^{\circ} 04^{\prime} \mathrm{E}$, covers approximately $1852 \mathrm{Km}^{2}$, area that is current shrinking at a rate estimated at 3\% per year (Ghosh et al 2015). Environmental events, such as silt deposition in the river bed and decrease in sweet water influx in the estuaries along with some anthropogenic effects led to the increase in substrate salinity in the Sundarbans region (Dasgupta et al 2014). Soil salinity in Sundarbans was recorded to be 27 ppt (Nandy et al 2007). Such factors have devastating results to some mangrove taxa (Parani et al 2000). Some plants like Heritiera fomes, Xylocarpus granatum, X. mekongensis and, Nypa fruticans, Aegialitis rotundifolia are on the verge of extinction (IUCN Red list 2016).

Reactive Oxygen Species (ROS), an inevitable byproduct of metabolism (respiration and photosynthesis), are produced in mitochondria, peroxisomes and chloroplast in plants (Sharma et al 2012). Bhattachrjee (2005) reported that almost $1-2 \%$ of oxygen taken up by plants is channelized to the production of ROS. Electron is leaked out of the photosynthetic electron transport chain to molecular $\mathrm{O}_{2}$, forming reduced forms of $\mathrm{O}_{2}$ such as hydrogen peroxide $\left(\mathrm{H}_{2} \mathrm{O}_{2}\right)$, superoxide $\left(\mathrm{O}_{2}\right)$ and hydroxyl radical $(\mathrm{OH})$. Chlorophylls when in triplet excited form, produce singlet oxygen $\left({ }^{1} \mathrm{O}_{2}\right)$ by transferring excitation energy (Triantaphylides \& Havaux 2009) . ROS plays a substantial role as signaling molecule in plants regulating various active processes, ie growth and development, responding to various abiotic and biotic environmental stresses and programmed cell death (Miller et al 2007). Abiotic stress includes Plant cells, in order to endorse proper growth and development, need to maintain cellular homeostasis by scavenging the excess ROS. Whether the role of ROS would be damaging, protective or signal transduction depends on the delicate balance in the plant cell between ROS production and detoxifying at the appropriate time and point (Gratao et al 2005). 
The aggravate production of ROS in plants during stress is now well evident (Imaly 2003). High temperature, salinity, metal ions, extreme irradiation, and water logging are considered as different mode of abiotic stress (Nakashima et al 2014). This excess ROS, if unattended, leads to irreversible damage to carbohydrate, protein, nucleic acid and lipid cause apoptosis of the cell (Sanchez et al 2014).

Excess substrate salinity is one of the critical factors in mangrove sustainability. Plants face difficulty in water and nutrients uptake from the soil as high deposition of salt in the substrate leads to low water potential in soil that causes physiological draught (Mahajan \& Tuteja 2005). Major hostile effect of saline stress on plants include ionic and osmotic imbalance, disorganization of cell membrane, reticence of cell division and growth, diminution in photosynthesis and augmented production of ROS (Donglar et al 2010). To combat this situation plants have evolved certain mechanisms in order to achieve sustainability. They accumulate low molecular proteins and compatible organic solutes such as proline and betain in the cytoplasm for osmotic adjustments. Plants either use ion transporters to extrude salt through the plasma membrane (Shi et al 2000) or use tonoplast transporters to keep them in vacuoles (Gaxiola et al 1999). To encounter increased ROS production, plants activate antioxidant enzymes and potent secondary metabolites (Parida et al 2004, Dasgupta et al 2010-2014).

Mangrove vegetation constantly confronts hostile environmental conditions. In such stressed condition, enhanced production of ROS in plant cells have to scavenge hypothetically for proper growth of the plants. In that context, we assessed the concentration of antioxidant secondary metabolites (i.e. Tannin and Proanthocyanidin) and the different radical scavenging ability of five mangrove species collected from five different Sites in the Indian Sundarbans with varying salinity. Among the five taxa, three species (i.e. Excoecaria agallocha, Bruguiera gymnorrhiza and Phoenix paludosa) are growing profusely in the Indian Sundarbans whereas the other two, (Xylocarpus granatum and Heritiera fomes) are on the verge of extinction. The main objective of the study was to quantify the extent of adaptability of five species in the high saline Indian Sundarbans area in relation to comparative antioxidant scavenging ability in different species.

\section{MATERIALS AND METHOD}

Shoot bud and young leaves were collected from matured mangrove plants (about 12-15 years) representing five taxa, two of which (Xylocarpus granatum and Heritiera fomes) are in vulnerable condition. Three taxa (Excoecaria agallocha, Bruguiera gymnorrhiza and Phoenix paludosa) are growing profusely in the same regime. Collection Sites (Fig. 1 A-D) were in five different islands in the Indian Sundarbans, namely Sajnekhali (Site II$22^{\circ} 08^{\prime} 48^{\prime \prime} \mathrm{N}, 88^{\circ} 50^{\prime} 10^{\prime \prime} \mathrm{E}$ ), Sudhanyakhali (Site III- $22^{\circ} 07^{\prime} 35^{\prime \prime} \mathrm{N}, 88^{\circ} 48^{\prime}$ 


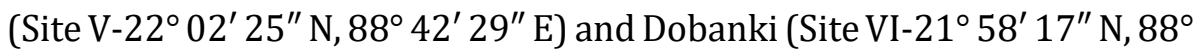
$45^{\prime} 57^{\prime \prime}$ E). Soil salinity of these Sites were $11.77 \pm 2.1,12.25 \pm 1.96,12.4 \pm$ $1.18,13.98 \pm 2.29$ and $15.27 \pm 2.17$ ppt respectively (Dasgupta et al 2012). Replicas of all the five species in controlled mesophytic condition at the garden of Indian Statistical Institute, Kolkata (Site I) approximately 2 ppt, (Dasgupta et al 2011), were also taken for comparative study. Fig. 2 shows the habitat of the five species considered.

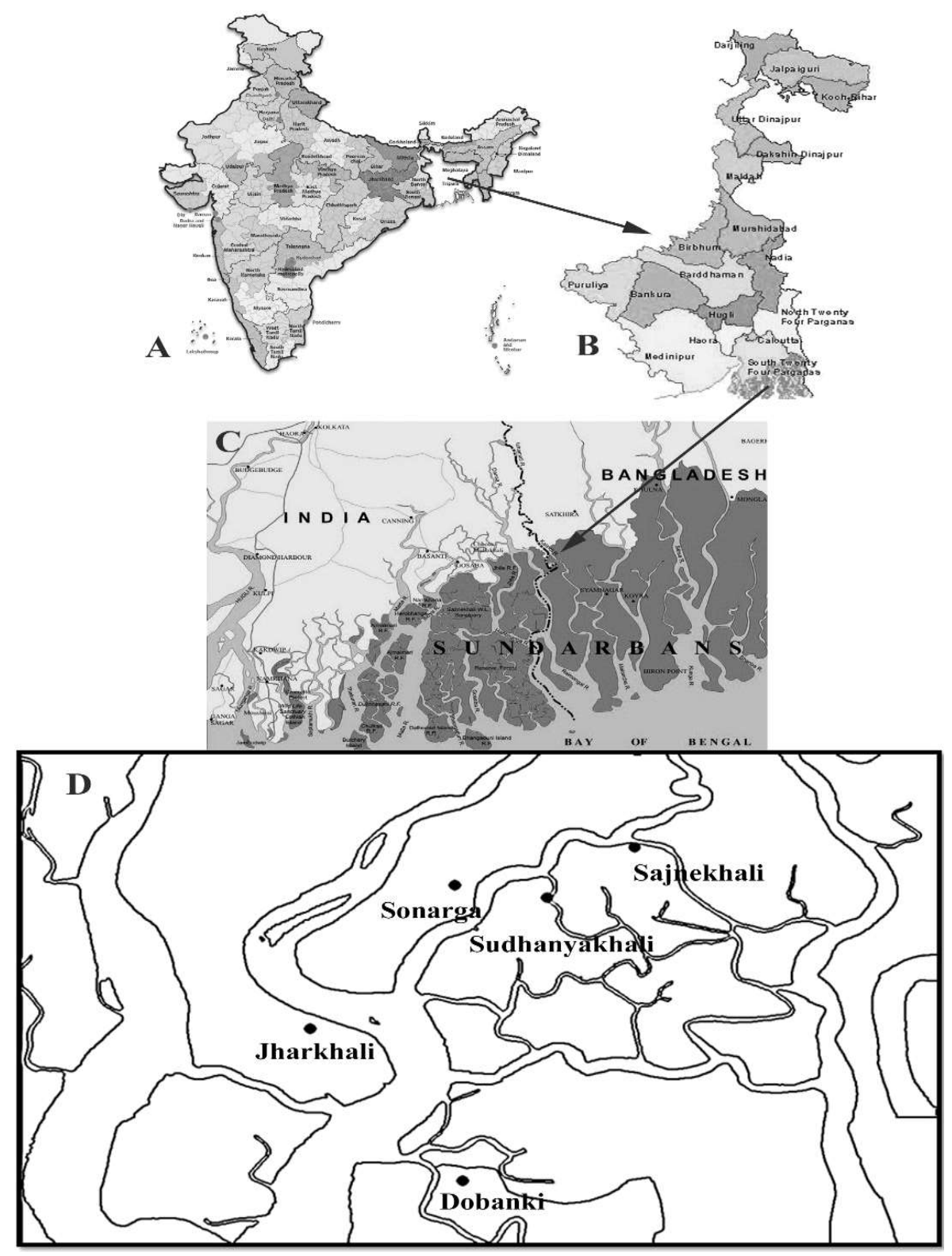

Fig. 1 A-D. Site maps: A-Map of India, B-Map of West Bengal, C-Map of Sundarbans mangrove forest and D-Expanded map of collection sites in the islands of Sundarbans 


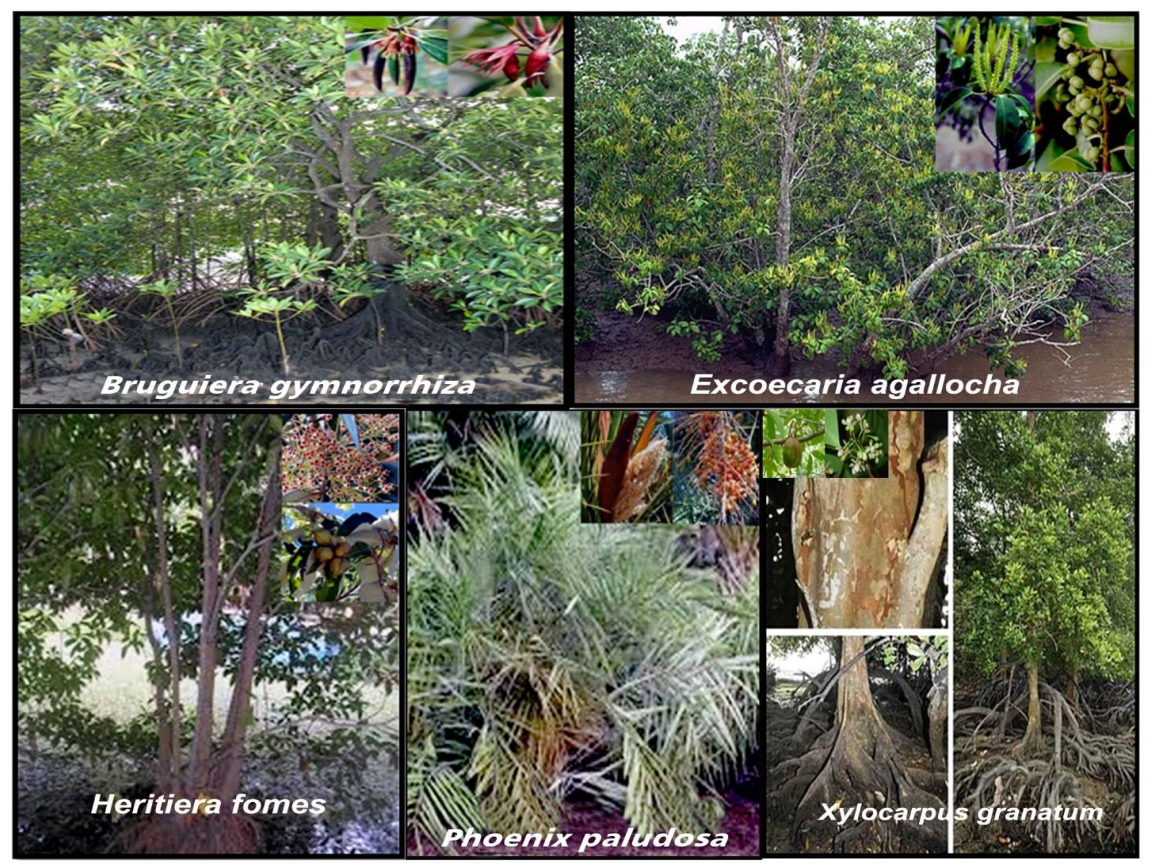

Figure 2. Habitat of the five mangrove species

\section{Extraction of Leaf Materials}

The plant materials collected from the six Sites were shade dried for a period of 2-3 months. Then they were ground to produce fine homogenous powders using an electric blender. Ten grams of each of the powdered samples was stirred overnight in magnetic stirrer with $100 \mathrm{ml}$ of $95 \%$ methanol at room temperature. They were vortexed vigorously for 3-5 minutes, then filtered and centrifuged at $6000 \mathrm{Rpm}$ for 15 minutes. This procedure was repeated thrice. Rotary evaporator (Neocool Circulator, CF 300 , Yamato) was then used to dry out the supernatant. The concentrated extracts stored at $-20^{\circ} \mathrm{C}$ (Huda-Faujan et al 2009). The working solution was made of aliquots of the extract were dissolved in $95 \%$ methanol to achieve $1 \mathrm{mg} / \mathrm{ml}$ solution.

\section{Secondary Metabolites}

Estimation of proanthocyanidin. Sun et al (1998) was followed for assessing total Proanthocyanidin content of the plant material. Different aliquots of the extractants (ranging from $0.05-0.3 \mathrm{mg} \mathrm{ml}^{-1}$ ) were taken for this experiment, along with $3 \mathrm{ml}$ of $4 \%$ vanillin solution and $1.5 \mathrm{ml}$ of hydrochloric acid. It was allowed to incubate for 15 minutes at room temperature, following which optical density was measured at 500nm. Catechin was used as the positive control. Result was expressed as Catechin equivalents in $\mathrm{mg} \mathrm{g}^{-1}$ of dry material. 
Estimation of Tannin. Europeans Commission (2000) reference method was followed to determine the total tannin content present in plant material. Different aliquots of the extractant (ranging from $0.05-0.3 \mathrm{mg} \mathrm{ml}^{-1}$ ) were mixed with $200 \mu \mathrm{l}$ of freshly prepared $0.35 \%$ ferric ammonium citrate, $200 \mu \mathrm{l}$ of $0.8 \%$ ammoniac. The absorbance was read at $525 \mathrm{~nm}$. Tannic Acid was used as positive control. Tannin content was calculated as Tannic Acid Equivalent (TAE) $\mathrm{mgg}^{-1}$ dry weight.

Antioxidative Ability Assays

Reducing power assay. The method described by Oyaizu (1986) was followed for this assay. A $0.1 \mathrm{ml}$ of extract containing different aliquots i.e. $0.05-0.3 \mathrm{mg} \mathrm{ml}^{-1}$ concentration of the extract were mixed with $0.1 \%$ Potassium hexacyanoferrate and $0.2 \mathrm{M}$ phosphate buffer ( $\mathrm{pH}$ 6.6). 10 percent Trichloro acetic acid was added to the reaction mixture after 20 minutes incubation at $50^{\circ} \mathrm{C}$ which was then subjected to centrifugation at $3000 \mathrm{rpm}$ for 10 minutes. Upper layer of the solution $(2.5 \mathrm{ml})$ was next mixed with $2.5 \mathrm{ml}$ distilled water and $0.5 \mathrm{ml}$ of freshly prepared $0.1 \%$ ferric chloride solution. The absorbance was read at $700 \mathrm{~nm}$ following incubation period of 10 minutes at room temperature. Ascorbic acid was the positive control. Reducing power of the plant samples were expressed as Ascorbic Acid Equivalent (AAE) mg per gram of dry weight.

Determination of the effects on Peroxynitrite. Beckman et al (1994) was followed for synthesis of peroxynitrite (ONOO). Mixed with $5 \mathrm{ml}(0.7 \mathrm{M})$ hydrogen peroxide $0.6 \mathrm{M}$ hydrochloric acid, to which on ice bath $5 \mathrm{ml}$ of $0.6 \mathrm{M}$ potassium nitrite was added for 1 second. Then a $5 \mathrm{ml}$ ice cold sodium hydroxide $1.2 \mathrm{M}$ was added. Granular manganese dioxide prewashed with $(1.2 \mathrm{M}) \mathrm{NaOH}$ was used to remove the excess $\mathrm{H}_{2} \mathrm{O}_{2}$. The reaction mixture was kept overnight at $-20^{\circ} \mathrm{C}$. Peroxynitrite solution was pipetted out from the top of the frozen mixture the following day. Concentration of this Peroxynitrite was measured by the absorption measured spectrophotometrically at $302 \mathrm{~nm}(\varepsilon=1670 / \mathrm{M} \mathrm{cm})$. Peroxynitrite scavenging activity of the plant extracts were estimated following the Evans blue bleaching assay method as described by Bailly et al (2000). The reaction mixture had ( $\mathrm{pH}$ 7.4) 50mM phosphate buffer, Diethelyn Triamine Pentaacetic Acid (DTPA) (0.1mM), 90mM sodium chloride, and $5 \mathrm{mM}$ potassium chloride, $12.5 \mathrm{mM}$ Evans Blue, $1 \mathrm{mM}$ peroxynitrite and different concentrations of the plant extract $\left(0.05-0.3 \mathrm{mg} \mathrm{ml}^{-1}\right)$ in a final volume of $4 \mathrm{ml}$. Absorbance was read at $611 \mathrm{~nm}$ following an incubation period of 30 minutes at $25^{\circ} \mathrm{C}$. Gallic acid was used as the positive control in this experiment.

Reaction with hypochlorous Acid. Freshly prepared hypochlorous acid ( $\mathrm{HOCl}$ ) was used. $0.6 \mathrm{M}$ sulfuric acid was added to $10 \%$ solution of $\mathrm{NaOCl}$ to 
adjust the $\mathrm{pH}$ to 6.2 and concentration of the formed $\mathrm{HOCl}$ were determined using spectrophotometer, absorbance read at $235 \mathrm{~nm}$ and molar extinction coefficient 100/M cm (Aruoma \& Halliwell 1987). $4 \mathrm{ml}$ reaction mixture contained $(\mathrm{pH} 6.8) 50 \mathrm{mM}$ phosphate buffers, $8.4 \mathrm{mM}$ $\mathrm{HOCl}$, catalase $(7.2 \mathrm{mM})$ and varying concentrations $\left(0.05-0.3 \mathrm{mg} \mathrm{ml}^{-1}\right)$ of the plant extract. Reaction mixture was incubated for 20 minutes at $25^{\circ} \mathrm{C}$. This scavenging activity was evaluated by measuring the decrease in absorbance at $404 \mathrm{~nm}$. Ascorbic acid was used as positive control.

Hydroxyl radical scavenging activity. The method described by Elizabeth and Rao (1990) was adopted while assessing the hydroxyl radical $(\mathrm{OH})$ scavenging activity of the plant extracts. The radicals were generated by Fenton reaction. This assay is based on the quantification of the 2-deoxyribose degradation product, by its condensation with TBA. $4 \mathrm{ml}$ reaction mixture contained 2-deoxy-2-ribose $(2.8 \mathrm{mM})$, potassium phosphate buffer $(20 \mathrm{mM}) \mathrm{pH} 7.4,100 \mathrm{mM}$ ferric chloride, 100mM EDTA, $1.0 \mathrm{mM}$ hydrogen peroxide, $100 \mathrm{mM}$ ascorbic acid and different concentrations $\left(0.05-0.3 \mathrm{mg} \mathrm{ml}^{-1}\right)$ of sample. $2 \mathrm{ml} 2.8 \%$ TCA was added to $1 \mathrm{ml}$ of the mixture after 1 hour incubation at $37^{\circ} \mathrm{C}$. Then $2 \mathrm{ml} 1 \%$ aqueous TBA solution was added to the reaction mixture; the reactant was incubated at $90^{\circ} \mathrm{C}$ for 15 minutes. The absorbance was measured at $532 \mathrm{~nm}$. Mannitol was used as positive control.

Nitric oxide radical scavenging. Following Garrat (1964), nitric oxide (NO) formed from aqueous sodium nitroprusside (SNP) solution at physiological $\mathrm{pH}$ produce nitrite ions by interacting with oxygen, which was measured by GriessIllosvoy reaction. Reaction mixture for this experiment had ( $\mathrm{pH} 7.4)$ phosphate buffered saline, SNP (10mM) and different concentrations $\left(0.05-0.3 \mathrm{mg} \mathrm{ml}^{-1}\right)$ of test solution. This $3 \mathrm{ml}$ reaction mixture was subjected to incubation at $25^{\circ} \mathrm{C}$ for 150 minutes. Then $2 \mathrm{ml}$ of sulfanilamide $(0.33 \%$ in $20 \%$ glacial acetic acid) was then added to $1 \mathrm{ml}$ of the solution, which was then allowed to stand for 5 minutes. Next $2 \mathrm{ml}$ of $0.1 \%$ Napthyl ethylene diamine dihydrochloride (NED) was added and the mixture was subjected to incubation for 30 minutes at $25^{\circ} \mathrm{C}$. Pink chromophore formed as a result of diazotization of nitrite ions with sulphanilamide and succeeding coupling with NED was measured using spectrophotometer at 540nm. Curcumin was used as positive control in the same concentration as the sample.

Singlet oxygen scavenging activity assay. Procedure adopted by Pedraza-Chaverrı' et al (2004) was followed to measure the production of singlet oxygen $\left({ }_{1} \mathrm{O}^{2}\right)$. Singlet oxygen was produced by a reaction among sodium hypochlorite and hydrogen peroxide and the RNO bleaching was read at $440 \mathrm{~nm}$. Final volume of $4 \mathrm{ml}$ contained $45 \mathrm{mM}$ phosphate buffer, $\mathrm{pH}$ 7.1, $50 \mathrm{mM} \mathrm{NaOCl}, 50 \mathrm{mM} \mathrm{H}_{2} \mathrm{O}_{2}, 10 \mathrm{mM}$ RNO $50 \mathrm{mM}$ L-histidine and differing 
aliquots of the test sample $\left(0.05-0.3 \mathrm{mg} \mathrm{ml}^{1}\right)$. Reaction mixture was allowed to be incubated at $30^{\circ} \mathrm{C}$ for 40 minutes and decrease in the absorbance was measured using spectrophotometer. Lipoic acid was used as positive control.

Hydrogen peroxide scavenging activity assay. Protocol adopted following Long et al (1999) was used to assess the hydrogen peroxide $\left(\mathrm{H}_{2} \mathrm{O}_{2}\right)$ scavenging activity of the plant samples. The reaction mixture contained aliquot of $\mathrm{H}_{2} \mathrm{O}_{2}(50 \mathrm{mM})$ and different concentrations (0.05-0.3 $\mathrm{mg} \mathrm{ml}^{-1}$ ) of samples in equal quantity. The mixture was allowed to incubate at room temperature for 30 minutes. Following incubation, the $\mathrm{H}_{2} \mathrm{O}_{2}$ sample solution was mixed with $50 \mu \mathrm{l}$ methanol. A $4.5 \mathrm{ml}$ FOX reagent (prepared by mixing 9 volumes of $4.4 \mathrm{mM}$ BHT in methanol with 1 volume of $2.56 \mathrm{mM}$ ammonium ferrous sulfate in $0.25 \mathrm{M} \mathrm{H}_{2} \mathrm{SO}_{4}$ and $1 \mathrm{mM}$ xylenol orange) was added to this solution. The reaction solution was then mixed using vortex and subjected to incubation at room temperature for 30 minutes. The absorbance was measured at $560 \mathrm{~nm}$. Positive control for this experiment was sodium pyruvate.

Superoxide radical scavenging activity assay. Procedure of Fontana et al (2001) was followed for studying Superoxide Radical scavenging activity. It was done for the reduction of tetrazolium nitro blue (NBT). The nonenzymatic phenazine methosulfate - nicotinamide adenine dinucleotide (PMS/NADH) system produces superoxide radicals $\left(\mathrm{O}^{2-}\right)$ that reduce NBT into a purple-colored substance. The reaction solution had (pH 7.4) $20 \mathrm{mM}$ phosphate buffer, $50 \mathrm{mM}$ NBT, 73mM NADH, 15mM PMS and different concentrations $\left(0.05-0.3 \mathrm{mg} \mathrm{ml}^{-1}\right)$ of the sample mixture. The absorbance was measured at $56 \mathrm{~nm}$ following incubation for 5 minutes at room temperature. Quercetin was used as positive control.

Scavenging activity of the extract for each of the assay was calculated as:

$$
\text { Scavenging Activity }(\%)=\left\{\frac{A c-A t}{A c}\right\} \times 100
$$

Here $A c$ is the absorbance of the blank reaction and $A t$ is the absorbance of sample of the extracts.

$\mathrm{Ic}_{50}$ which expresses the concentration of the plant extract that's required to scavenge $50 \%$ of the radicals present was calculated by the following equation in all free radical scavenging assays:

$$
\mathrm{Ic}_{50}=\left\{\frac{\text { percent inhibition }}{\text { Concentration of the sample }}\right\} \times 50
$$

All the samples were assayed in triplicates. These tests were performed thrice a year; in summer, rainy season and winter over a period of three years. 


\section{Statistical Analysis}

A two-tailed bivariate correlation coefficient (Pearson coefficient) was calculated for assessing the bivariate correlation among the different studied antioxidant characteristics for all the five studied taxa. Different parameters of ROS scavenging activity with the variations of substrate salinity were taken into account. SPSS-12 software was used for this statistical analysis.

\section{RESULTS}

\section{Estimation of Secondary Metabolites}

\section{Estimation of Proanthocyanidin}

Proanthocyanidin, known as condensed tannins, belong to the oldest of plant secondary metabolites and are strong antioxidants. Catechin was used as the positive control for this study and the value was expressed as Catechin equivalent $\mathrm{mg} \mathrm{g}^{-1}$ dry weight. Proanthocyanidin amount on the contrary was relatively higher in $H$. fomes and $X$.granatum than the other three profusely growing taxa, but their amount was found to be highly unstable along the salinity gradient. The total amount of Proanthocyanidin in the three profusely growing taxa increased gradually along the salinity gradient, although very slowly. In the two degrading taxa both the values on the most distant Site along the salinity gradient were extreme. In case of $H$. fomes, the amount of this secondary metabolite was found to be highest in Site IV at 40.15 at $0.3 \mathrm{mg} \mathrm{ml}^{-1}$ extract concentration (Fig. 3a). It decreased to 24.85 in Site $V$ and again increased to 32.65 in Site VI; both at $0.3 \mathrm{mg} \mathrm{ml}^{-1}$ extract concentration. $X$. granatum on the other hand showed a drop

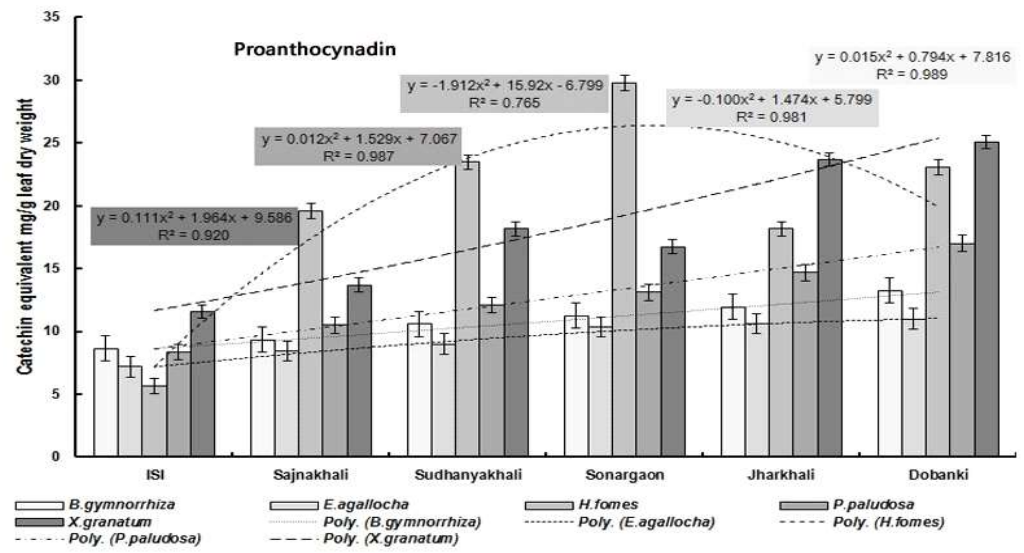

Figure 3a. Proanthocyanidin 
in the Proanthocyanidin amount in Site IV to 22.45 at $0.3 \mathrm{mg} / \mathrm{ml}$ extract concentration after gradual increment up to Site III along the salinity gradient (25.36 at $0.3 \mathrm{mg} \mathrm{ml}^{-1}$ extract concentration); the next two Sites again showed increment as 31.35 and 32.15 respectively at $0.3 \mathrm{mg} \mathrm{ml}^{-1}$ extract concentration. The $\mathrm{R}^{2}$ values elucidated from the trend line graph $-0.989,0.981,0.765,0.987$, and 0.920 respectively for $B$. gymnorrhiza, E. agallocha, H. fomes, P. paludosa and X. granatum shows the better fit of the curves for the three profusely growing plants.

\section{Estimation of Tannin}

Content of tannin, a potent antioxidant was found to be relatively high in E. agallocha in the six habitats than the rest of the plant species, with the highest being in Site VI at 91.35 at $0.3 \mathrm{mg} \mathrm{ml}^{-1}$ extract concentration. Tannic acid was used as the positive control in this study and the total amount of tannin was expressed as Tannic Acid Equivalent (TAE) $\mathrm{mg} \mathrm{g}^{-1}$ dry weight. Total tannin content was very low in the two degrading species, $H$. fomes and $X$. granatum. The highest amount was recorded at Site IV in $H$. fomes as 33.57 at $0.3 \mathrm{mg} \mathrm{ml}^{-1}$ extract concentration and at Site V in X. granatum as 29.47 at $0.3 \mathrm{mg} \mathrm{ml}^{-1}$ extracts concentration, beyond which it started to decrease (Fig. $3 \mathrm{~b}$ ). The increment was gradual for B. gymnorrhiza and P. paludosa; here highest amount was recorded at 51.28 and 32.48 respectively at $0.3 \mathrm{mg}$ $\mathrm{ml}^{-1}$ extract concentration. The $\mathrm{R}^{2}$ values elucidated from the trend line graph were $0.986,0.979,0.954,0.987$, and 0.584 respectively for the five taxa in alphabetic order.

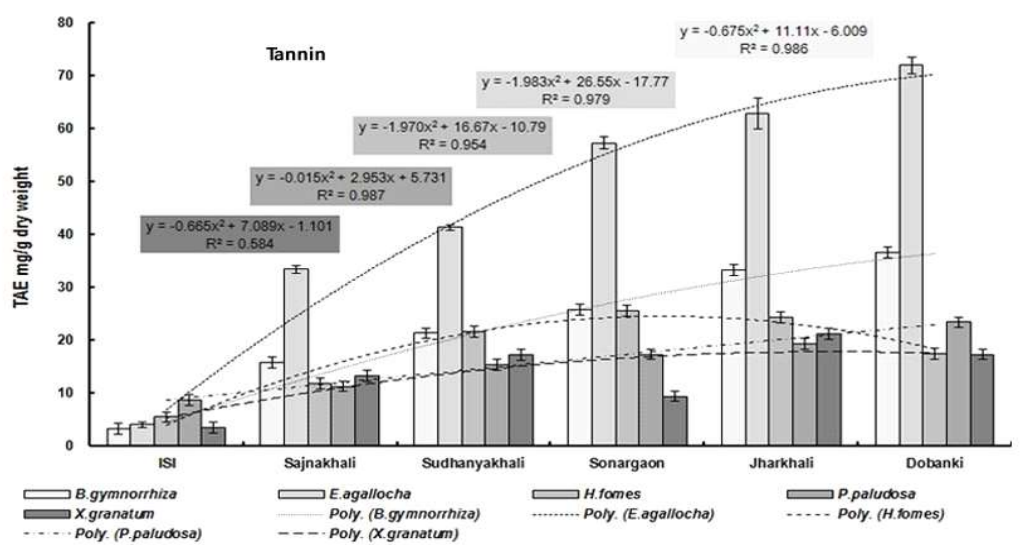

Figure 3b. Total Tannin 
Antioxidative Ability Assay

Reducing Power assay

The total reduction capability, where $\mathrm{Fe}^{3+}$ is reduced to $\mathrm{Fe}^{2+}$, was found to be higher in all the five taxa in the saline habitat from their mesophytic counterparts. Reducing power was calculated as Ascorbic Acid Equivalent (AAE) mg/g dry weight, where ascorbic acid was the positive control. Here again the amount of increase was found to be higher and gradual in E. agallocha, B. gymnorrhiza and P. paludosa than the other two, where in the total reducing power started to decrease after the IVth Site (30.15 and 28.98 respectively for $H$. fomes and $X$. granatum both at $0.3 \mathrm{mg} \mathrm{ml}^{-1}$ extract concentration). The maximum reducing power found were $34.41,34.97$ and 31.48 respectively in $E$. agallocha, B. gymnorrhiza and P. paludosa in the VIth Site at $0.3 \mathrm{mg} \mathrm{ml}^{-1}$ extract concentration (Fig. $3 \mathrm{c}$ ). The $\mathrm{R}^{2}$ values elucidated from the trend line graph were $0.987,0.998,0.969,0.980$ and 0.976 respectively for the five taxa in alphabetic order.

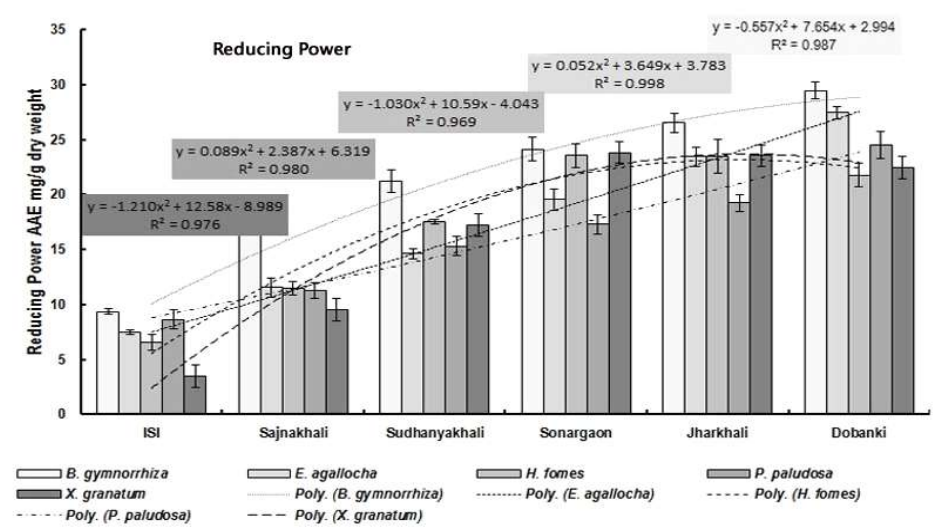

Figure 3c. Reducing power

Determination of the effects on Peroxynitrite

Results revealed that B. gymnorrhiza, E. agallocha and P. paludosa, steadily increased in the percent inhibition along the salinity gradient (Fig 4a). But this trend got discontinued at Site IV in H. fomes and Site III in X. granatum (36.39 and 37.83 respectively at $0.3 \mathrm{mg} \mathrm{ml}^{-1}$ extract concentration). Beyond these Sites, percent inhibition dwindled along the salinity gradient. Highest inhibition occurred at Site VI as 39.47 ( $B$. gymnorrhiza), 38.29 (E. agallocha) and 36.81 (P. paludosa). The positive control Gallic acid recorded the highest percent inhibition as 
65.35 at $0.3 \mathrm{mg} \mathrm{ml}^{-1}$ concentration. Incidence of $50 \%$ inhibition $\left(\mathrm{IC}_{50}\right)$ of cation radical scavenging depicted reverse picture of percent scavenging (Fig. 4b). Both highest and lowest $\mathrm{IC}_{50}$ were observed in E. agallocha as 0.64 and 0.176 at Site I and Site VI respectively at $0.175 \mathrm{mg} \mathrm{ml}^{-1}$ extract concentration. The $\mathrm{R}^{2}$ values elucidated from the trend line graph of percent inhibition at $0.175 \mathrm{mg} \mathrm{ml}^{-1}$ extract concentration were $0.995,0.984$, $0.924,0.977$ and 0.795 respectively for the five taxa in alphabetic order.

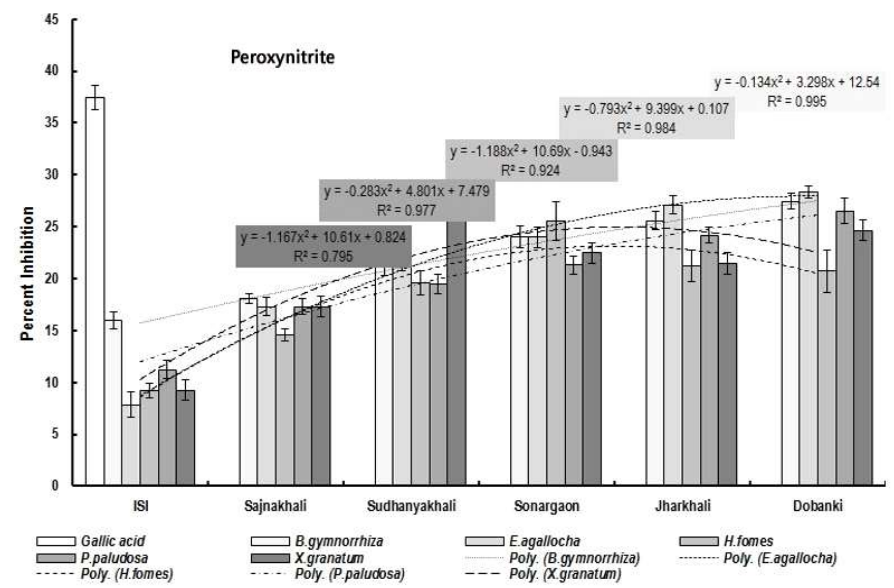

Figure 4a. Percent Inhibition of Peroxynitrite

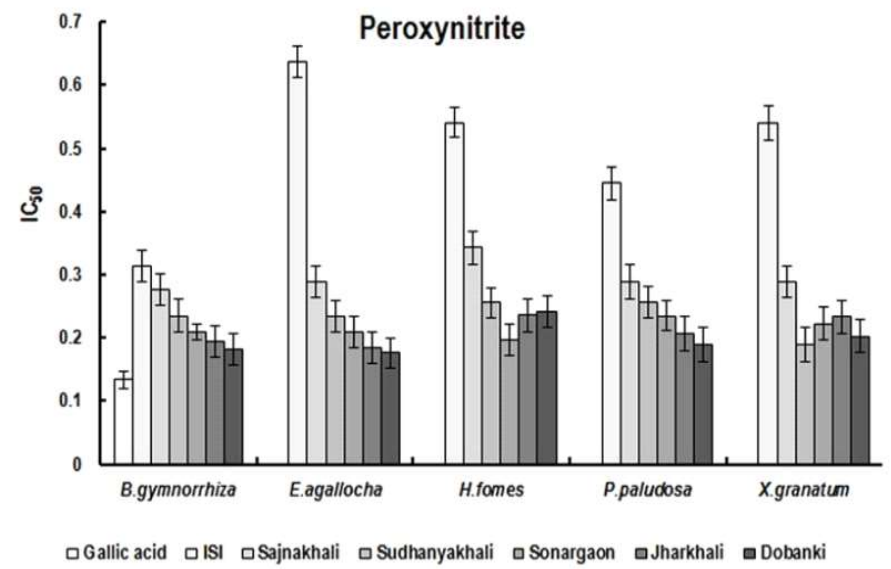

Figure 4b. Peroxynitrite

Reaction with Hypochlorous Acid

In this experiment, capacity to react with the Hypochlorous acid of all the plant taxa was examined. The percent inhibitions increased as the substrate salinity hiked in E. agallocha, B. gymnorrhiza and P. paludosa over the mesophytic individuals. But in $X$. granatum and $H$. fomes, the percent 
inhibition recorded were not as indicated in other three taxa, the percent inhibition decreased beyond the Site IV (32.54 and 39.8 respectively at 0.3 $\mathrm{mg} \mathrm{ml}^{-1}$ extract concentration) with the increase along the salinity gradient. Whereas E. agallocha, B. gymnorrhiza and P. paludosa showed highest magnitude of inhibition in Site VI as $46.58,46.57$ and 44.65 respectively at $0.3 \mathrm{mg} / \mathrm{ml}$ extract concentration. The positive control Ascorbic acid recorded the highest percent inhibition at 68.57 at $0.3 \mathrm{mg} \mathrm{ml}^{-1}$ concentration (Fig. 5a). $\mathrm{IC}_{50}$ values were calculated in all the cases (Fig. $5 \mathrm{~b}$ ). Highest $\mathrm{IC}_{50}$ was found to be in E. agallocha at 0.83 at Site I at $0.175 \mathrm{mg} \mathrm{ml}^{-1}$ extract concentration and the lowest in B. gymnorrhiza as 0.131 at Site VI also at $0.175 \mathrm{mg} \mathrm{ml}^{-1}$ extract concentration. The $\mathrm{R}^{2}$ values elucidated from the trend line graph of percent inhibition at $0.175 \mathrm{mg} \mathrm{ml}^{-1}$ extract concentration were $0.998,0.998,0.987,0.988$ and 0.991 respectively for the five taxa in alphabetic order.

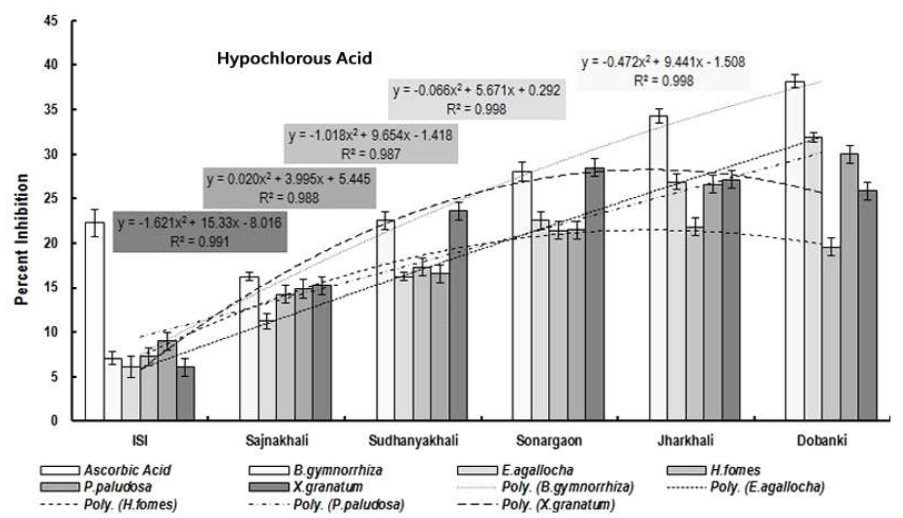

Figure 5a. Percent Inhibition of Hypochlorous Acid

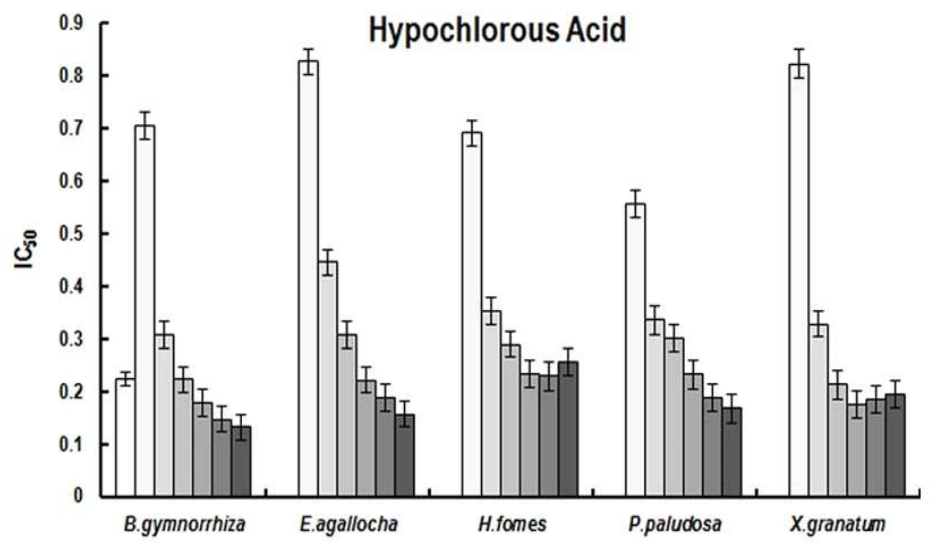

Figure 5b. Hypochlorous Acid 
Hydroxyl Radical Scavenging Activity

Results revealed that E. agallocha, B. gymnorrhiza and P. paludosa, steadily increased in the percent inhibition along the salinity gradient. But this trend has unobtainable at Site IV in $H$. fomes and $X$. granatum $(21.48$ and 23.29 respectively at $0.3 \mathrm{mg} \mathrm{ml}^{-1}$ extract concentration). Beyond these sites percent inhibition declined along the salinity gradient. Highest inhibition occurred at Site VI as 31.43 (B. gymnorrhiza), 30.48 (P. paludosa) and 25.37 (E. agallocha). The positive control Mannitol recorded the highest percent inhibition at 52.53 at $0.3 \mathrm{mg} \mathrm{ml}^{-1}$ concentration (Fig. 6a). Incidence of $50 \%$ inhibition $\left(\mathrm{IC}_{50}\right)$ of cation radical scavenging depicted reverse picture of percent scavenging. Both highest and lowest $\mathrm{IC}_{50}$ was observed in B. gymnorrhiza at 1.5 and 0.33 at Site I and Site VI respectively at $0.175 \mathrm{mg} \mathrm{ml}^{-1}$ extract concentration (Fig. 6b). The $\mathrm{R}^{2}$ values elucidated from the trend line graph of percent inhibition at $0.175 \mathrm{mg} \mathrm{ml}^{-1}$ extract concentration were $0.998,0.985,0.964,0.998$ and 0.964 respectively for the five taxa in alphabetic order.

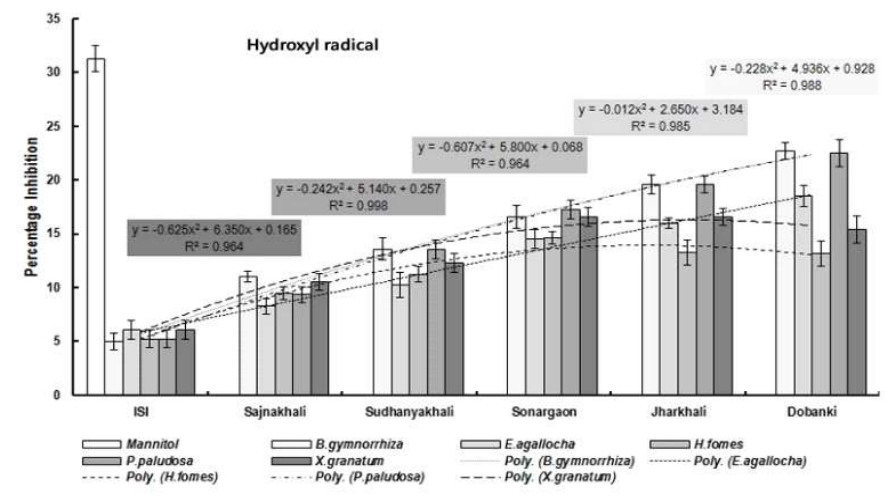

Figure 6a. Percent Inhibition of Hydroxyl radical

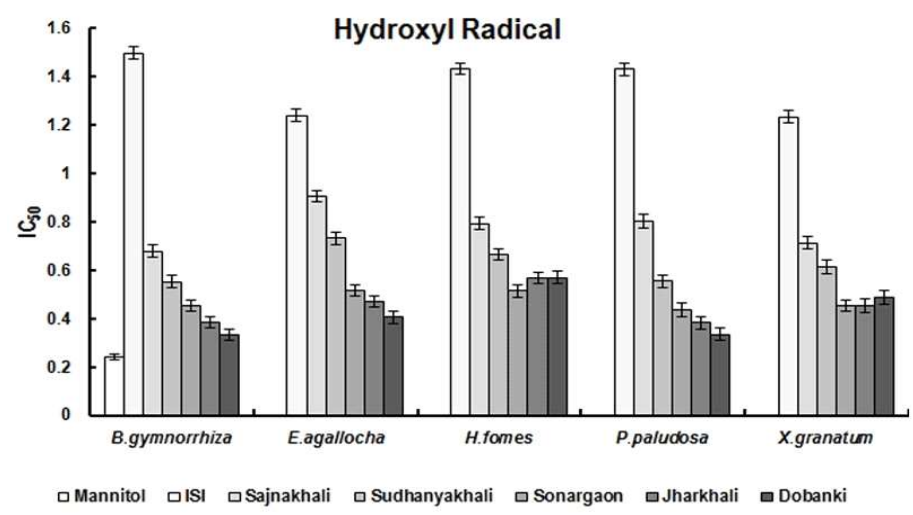

Figure 6b. Hydroxyl radical 


\section{Nitric Oxide Radical Scavenging}

In this experiment, Nitric oxide radical scavenging capacities of all the plants were examined. The percent inhibition increased as the substrate salinity hiked in E. agallocha, B. gymnorrhiza and P. paludosa over the mesophytic individuals. But in $X$. granatum and $H$. fomes, the percent inhibitions recorded were not as indicated in other three taxa, where the percent inhibition decreased beyond the Site IV (37.48 and 32.59 respectively at $0.3 \mathrm{mg} \mathrm{ml}^{-1}$ extract concentration) with the increase along the salinity gradient (Fig. 7d). Whereas B. gymnorrhiza, E. agallocha and P. paludosa showed highest magnitude of inhibition in Site VI as 65.38, 47.25 and 50.34 respectively at $0.3 \mathrm{mg} \mathrm{ml}^{-1}$ extract concentration. The positive control Curcumin recorded the highest percent inhibition at 64.22 at $0.3 \mathrm{mg} \mathrm{ml}^{-1}$ concentration. $\mathrm{IC}_{50}$ values were calculated for all the samples (Fig. $7 \mathrm{~b}$ ). Highest $\mathrm{IC}_{50}$ was found to be in P. paludosa as 0.95 at Site I at $0.175 \mathrm{mg} \mathrm{ml}^{-1}$ extract concentration and the lowest for E. agallocha as 0.14 at Site VI also at $0.175 \mathrm{mg}$ $\mathrm{ml}^{-1}$ extract concentration. The $\mathrm{R}^{2}$ values elucidated from the trend line graph of percent inhibition at $0.175 \mathrm{mg} \mathrm{ml}^{-1}$ extract concentration were $0.997,0.996$, $0.996,0.994$ and 0.997 respectively for the five taxa in alphabetic order.

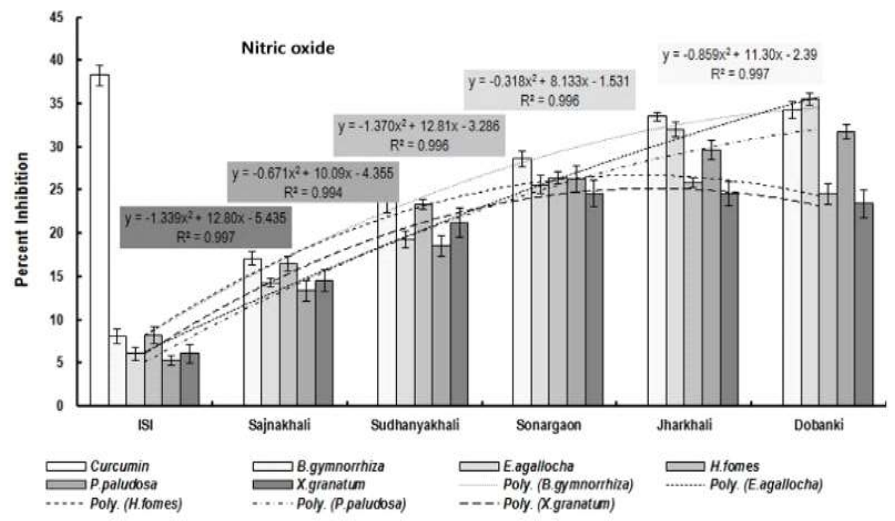

Figure 7a. Percent Inhibition of Nitric Oxide

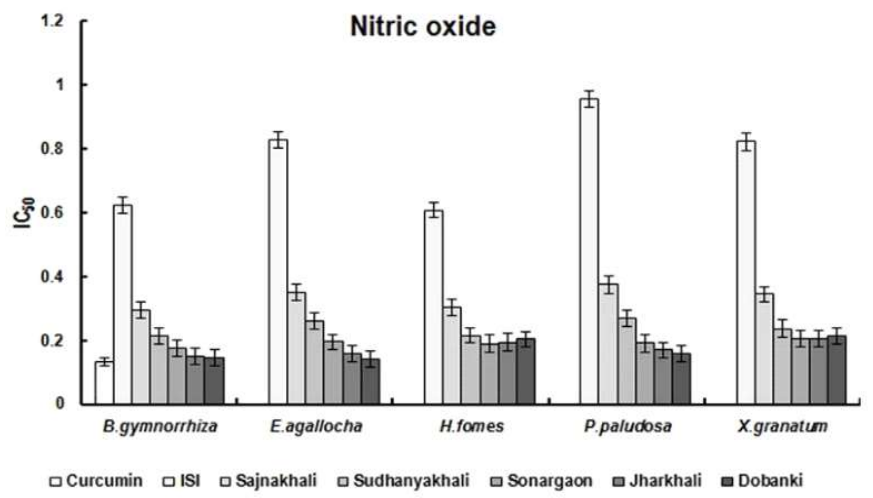

Figure 7b. Nitric Oxide 
Singlet Oxygen Scavenging Activity Assay

In this experiment, Singlet oxygen scavenging capacity of all the plants was examined. The percent inhibition increased as the substrate salinity hiked in E. agallocha, B. gymnorrhiza and P. paludosa over the mesophytic individuals. But in $X$. granatum and $H$. fomes, the percent inhibitions recorded were not as indicated in other three taxa, the percent inhibition decreased beyond the Site V and Site IV respectively (42.57 and 43.15 respectively at $0.3 \mathrm{mg} \mathrm{ml}^{-1}$ extract concentration) with the increase along the salinity gradient (Fig. 8a). Whereas B. gymnorrhiza, E. agallocha and $P$. paludosa showed highest magnitude of inhibition in Site VI at 56.48, 51.24 and 57.11 respectively at $0.3 \mathrm{mg} \mathrm{ml}^{-1}$ extract concentration. The positive control Lipoic acid recorded the highest percent inhibition at 81.54 at 0.3 $\mathrm{mg} \mathrm{ml}^{-1}$ concentration. $\mathrm{IC}_{50}$ values were calculated in all the cases, which reflected the usual reverse diagrams (Fig. $8 \mathrm{~b}$ ). Highest $\mathrm{IC}_{50}$ was found to be in $X$ granatum as 1.44 at Site I at $0.175 \mathrm{mg} \mathrm{ml}^{-1}$ extract concentration and the lowest for P. paludosa as 0.234 at Site VI also at $0.175 \mathrm{mg} \mathrm{ml}^{-1}$ extract concentration. The $\mathrm{R}^{2}$ values elucidated from the trend line graph of percent inhibition at $0.175 \mathrm{mg} \mathrm{ml}^{-1}$ extract concentration were $0.987,0.999$, $0.991,0.996$ and 0.980 respectively for the five taxa in alphabetic order.

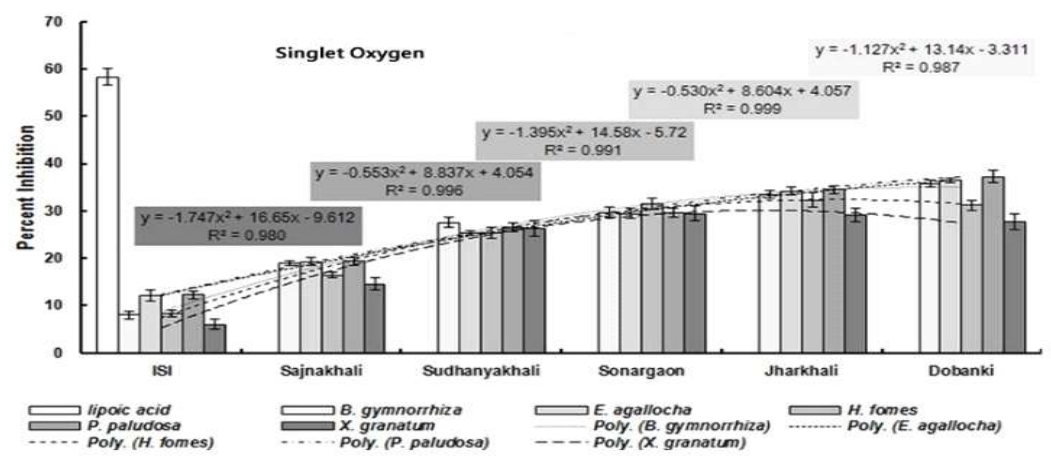

Figure 8a. Percent inhibition of Singlet oxygen

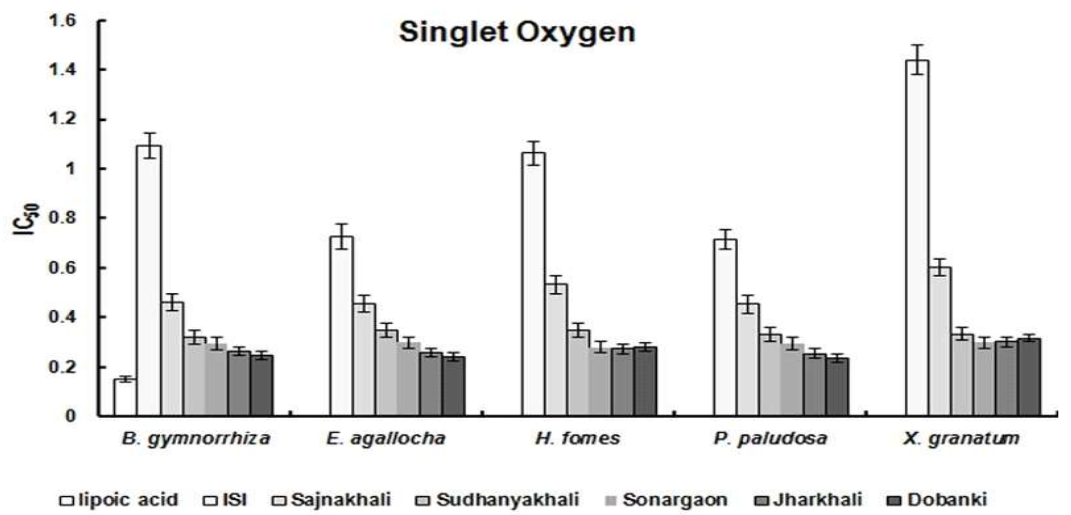

Figure 8b. Singlet oxygen 
Hydrogen Peroxide Scavenging Activity Assay

Hydrogen Peroxide scavenging capacity of all the plants, were measured. The experiment revealed that E. agallocha, B. gymnorrhiza and $P$. paludosa showed a steady increase in the percent inhibition along the salinity gradient, but this trend got discontinued at Site IV in H. fomes and $X$. granatum (23.67 and 38.46 respectively at $0.3 \mathrm{mg} \mathrm{ml}^{-1}$ extract concentration). Beyond these sites the percent inhibition dwindled along salinity gradient. Highest inhibition occurred at Site VI at $53.44(P$. paludosa), 48.22 (B. gymnorrhiza) and 48.24 (E. agallocha). The positive control Sodium pyruvate recorded the highest percent inhibition as 74.15 at $0.3 \mathrm{mg} \mathrm{ml}^{-1}$ concentration (Fig. 9a). Incidence of $50 \%$ inhibition $\left(\mathrm{IC}_{50}\right)$ of cation radical scavenging depicted reverse picture of percent scavenging (Fig. 9b). Highest $\mathrm{IC}_{50}$ was found to be in X. granatum at 1.44 at Site I at $0.175 \mathrm{mg} \mathrm{ml}^{-1}$ extract concentration and the lowest for B. gymnorrhiza as 0.231 at Site VI also at $0.175 \mathrm{mg} \mathrm{ml}^{-1}$ extract concentration. The $\mathrm{R}^{2}$ values elucidated from the trend line graph of percent inhibition at $0.175 \mathrm{mg} \mathrm{ml}^{-1}$ extract concentration were $0.989,0.998,0.972,0.998$ and 0.991 respectively for the five taxa in alphabetic order.

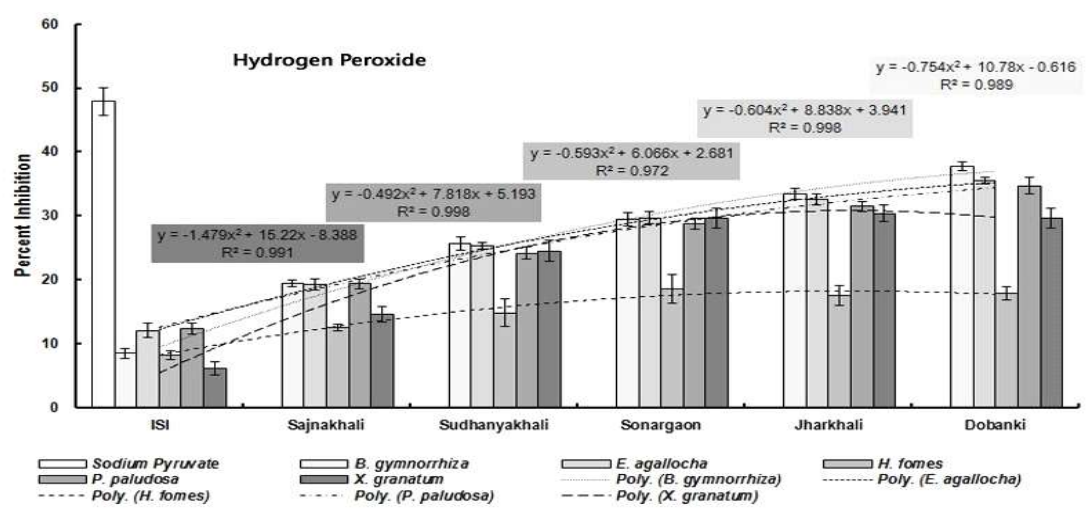

Figure 9a. Percent inhibition of Hydrogen Peroxide

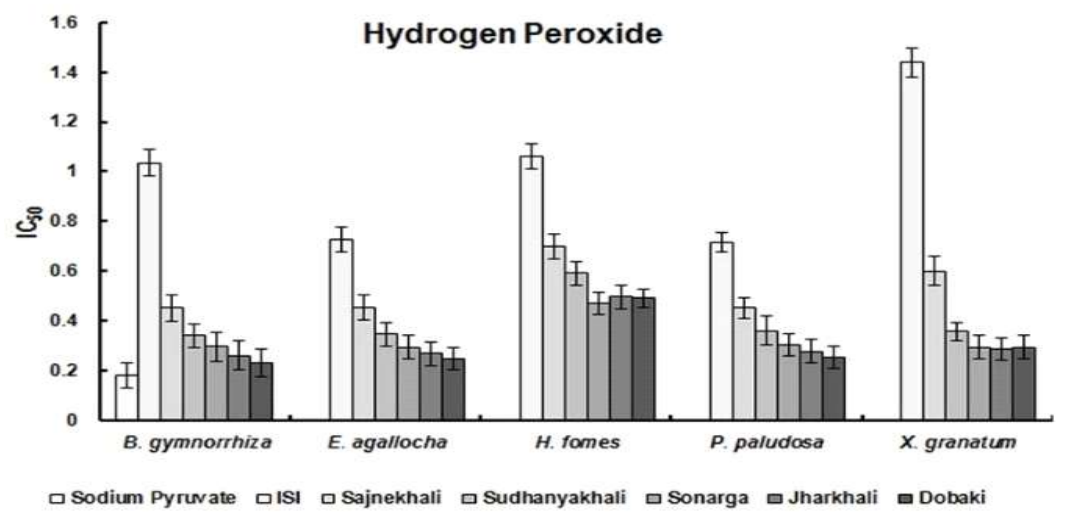

Figure 9b. Hydrogen Peroxide 
Superoxide Radical Scavenging Activity Assay

Scavenging capacity of the plants for the individual reactive oxygen species were assessed for better understanding of the ROS scavenging ability of these halophytes. Superoxide radical scavenging capacity increased for all the five species in Sundarbans habitat than their non-saline counterpart. In this assay, E. agallocha, B. gymnorrhiza and P. paludosa showed a gradual increase in the percent inhibition along the salinity gradient. But this trend got discontinued at Site IV in H. fomes and at Site V in X. granatum (23.67 and 39.48 respectively at $0.3 \mathrm{mg} \mathrm{ml}^{-1}$ extract concentration), beyond these Sites percent inhibition dwindled along the salinity gradient. Highest inhibition occurred at Site VI as 51.55 (P. paludosa), 48.24 (E. agallocha) and 48.22 (B. gymnorrhiza). The positive control Quercetin should the highest percent inhibition at 94.26 at $0.3 \mathrm{mg} / \mathrm{ml}$ concentration (Fig. 10a). Incidence of $50 \%$ inhibition $\left(\mathrm{IC}_{50}\right)$ of cation radical scavenging depicted reverse picture of percent scavenging (Fig. 10b). Highest $\mathrm{IC}_{50}$ was observed in $X$. granatum as 1.44 at Site I and lowest in P. paludosa as 0.18 both at $0.175 \mathrm{mg} \mathrm{ml}^{-1}$ extract concentration Site VI. The $\mathrm{R}^{2}$ values elucidated from the trend line graph of percent inhibition at $0.175 \mathrm{mg} \mathrm{ml}^{-1}$ extract concentration were $0.997,0.999$, $0.972,0.999$ and 0.972 respectively for the five taxa in alphabetic order.

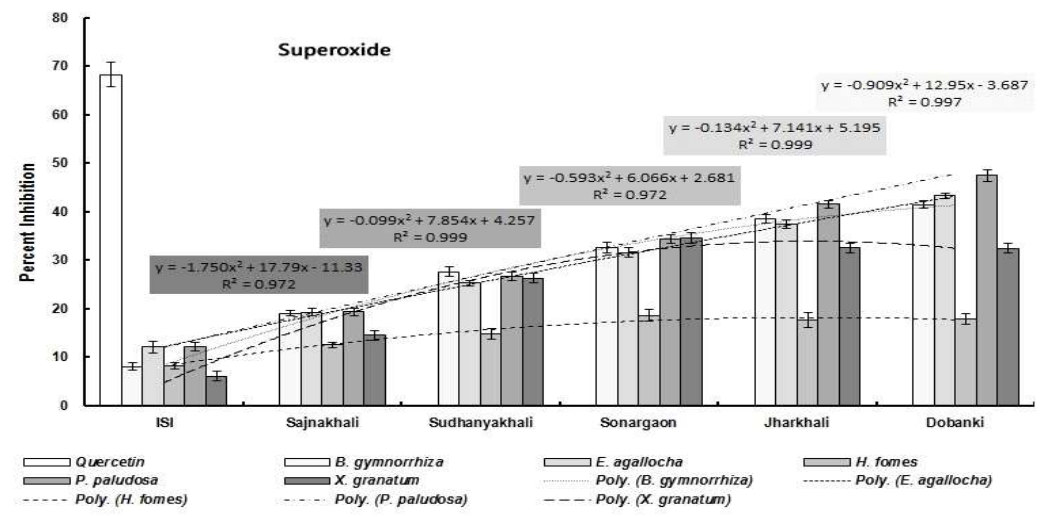

Figure 10a. Percent inhibition of Superoxide radical

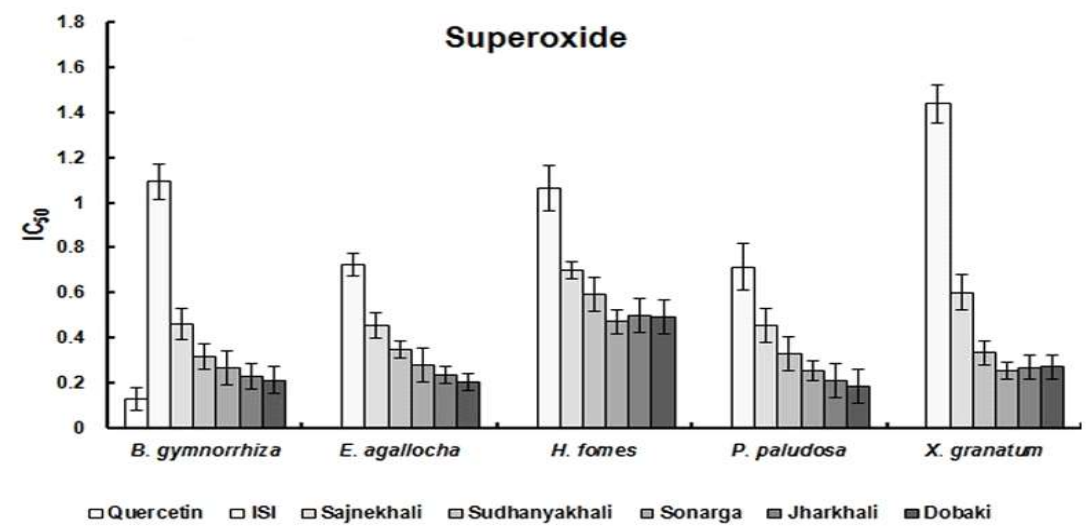

Figure 10b. Superoxide radical 
Table 1: Bivariate correlation of different radical scavenging ability and substrate salinity

\begin{tabular}{|c|c|c|c|c|c|c|}
\hline Treatment & B.gymnorrhiza & Eagallocha & Hfomes & P.paludosa & Xgranatum & Treatment \\
\hline Tannin & $0.989 * *$ & $0.974^{\text {** }}$ & 0.871 & $0.981^{\text {** }}$ & 0.754 & \multirow{10}{*}{ Salinity } \\
\hline Proanthrocyanidin & $0.978^{* *}$ & $0.982^{* *}$ & $0.941^{*}$ & $0.961^{*}$ & $0.974^{*}$ & \\
\hline Reducing Power & $0.974^{*}$ & $0.991^{\text {** }}$ & 0.731 & $0.994^{* *}$ & 0.871 & \\
\hline Superoxide & $0.979 * *$ & $0.987^{* *}$ & $0.974^{*}$ & $0.966^{*}$ & 0.875 & \\
\hline Hydrogen Peroxide & $0.963^{*}$ & $0.995^{\text {** }}$ & 0.901 & $0.991^{\text {*k }}$ & 0.867 & \\
\hline Singlet oxygen & $0.986^{* *}$ & $0.983^{\text {** }}$ & 0.624 & $0.974^{\text {** }}$ & $0.951^{*}$ & \\
\hline Nitric oxide & $0.974^{* *}$ & $0.991^{\text {*k }}$ & 0.871 & $0.987^{\text {*k }}$ & 0.935 & \\
\hline Hydroxyl & $0.987^{* *}$ & $0.978^{* *}$ & 0.745 & $0.967^{*}$ & 0.929 & \\
\hline Hypochlorous & $0.992^{* *}$ & $0.935^{* *}$ & 0.924 & $0.984^{* *}$ & 0.654 & \\
\hline Peroxinitrite & $0.971^{* *}$ & $0.987^{* *}$ & $0.947^{*}$ & $0.991^{\text {** }}$ & 0.768 & \\
\hline \multirow{7}{*}{ Tannin } & $0.978^{* *}$ & $0.976^{\text {** }}$ & 0.854 & $0.982^{* *}$ & 0.832 & Superoxide \\
\hline & $0.969^{* *}$ & $0.986^{\text {** }}$ & 0.911 & $0.994^{* *}$ & 0.761 & Hydrogen Peroxide \\
\hline & $0.983^{* *}$ & $0.981^{\text {** }}$ & 0.783 & $0.972^{*}$ & 0.322 & Singlet oxygen \\
\hline & $0.964^{*}$ & $0.983^{* *}$ & 0.872 & $0.983^{* *}$ & 0.673 & Nitric oxide \\
\hline & $0.987^{* *}$ & $0.971^{*}$ & 0.841 & $0.976^{* *}$ & 0.894 & Hydroxyl \\
\hline & $0.973^{* *}$ & $0.976^{\text {** }}$ & 0.768 & $0.982^{* *}$ & 0.570 & Hypochlorous \\
\hline & $0.991^{* *}$ & $0.985^{\text {** }}$ & $0.941^{*}$ & $0.971^{*}$ & 0.832 & Peroxinitrite \\
\hline Superoxide & $0.986^{* *}$ & $0.993^{* *}$ & 0.876 & $0.964^{*}$ & 0.908 & \multirow{7}{*}{ Proanthrocyanidin } \\
\hline $\mathrm{H} 2 \mathrm{O} 2$ & $0.979 * *$ & $0.962^{*}$ & 0.839 & $0.987^{* *}$ & 0.873 & \\
\hline $10-$ & $0.954^{*}$ & $0.978^{* *}$ & 0.851 & $0.978^{\text {** }}$ & 0.758 & \\
\hline N20 & $0.973^{*}$ & $0.974^{* *}$ & 0.863 & $0.984^{* *}$ & $0.944^{*}$ & \\
\hline $\mathrm{OH}$ & $0.983^{* *}$ & $0.986^{* *}$ & 0.836 & $0.972^{* *}$ & 0.869 & \\
\hline Hypochlorous & $0.976^{* *}$ & $0.991^{\text {** }}$ & 0.794 & $0.977^{* *}$ & 0.842 & \\
\hline Peroxinitrite & $0.982^{* *}$ & $0.942^{*}$ & 0.877 & $0.986^{* *}$ & 0.728 & \\
\hline \multirow{7}{*}{ Reducing Power } & $0.990^{* *}$ & $0.972^{*}$ & 0.890 & $0.981^{* *}$ & 0.849 & Superoxide \\
\hline & $0.978^{* *}$ & $0.987^{\text {** }}$ & 0.782 & $0.991^{* *}$ & 0.759 & $\mathrm{H} 2 \mathrm{O} 2$ \\
\hline & $0.973^{* *}$ & $0.974^{* *}$ & 0.907 & $0.947^{*}$ & 0.843 & $10-$ \\
\hline & $0.947^{*}$ & $0.981^{\text {** }}$ & 0.871 & $0.953^{*}$ & 0.738 & N20 \\
\hline & $0.989 * *$ & $0.939 *$ & 0.840 & $0.984^{* *}$ & 0.582 & $\mathrm{OH}$ \\
\hline & $0.975 * *$ & $0.978^{* *}$ & 0.879 & $0.967^{*}$ & 0.851 & Hypochlorous \\
\hline & $0.985 * *$ & $0.974^{* *}$ & 0.773 & $0.987^{* *}$ & 0.573 & Peroxinitrite \\
\hline
\end{tabular}

** Correlation is significant, $\mathrm{p} \leq 0.01$ level (2-tailed).

${ }^{*}$ Correlation is significant, $\mathrm{p} \leq 0.05$ level ( 2 -tailed).

\section{Relationship between Substrate Salinity and Radical scavenging ability}

A bi-tailed bivariate correlation coefficient (Pearson coefficient) was calculated among soil substrate salinity and each of the earlier presented parameters (Table 1). The analysis showed a strong correlation between the two secondary metabolites estimated and soil salinity for the three profusely growing taxa, i.e. E. agallocha, B. gymnorrhiza and P. paludosa. Both the parameters produced a correlation significant at 0.01 levels; except of correlation among Proanthocyanidin and salinity in P. paludosa, wherein correlation significance was at 0.05 levels. Relatively lesser correlation was observed in $H$. fomes and $X$. granatum, correlation $(0.05$ level) Proanthocynadin and salinity. Significant correlation was observed among the 7 antioxidative assays and salinity in B. gymnorrhiza, E. agallocha and P. paludosa. However level of significance of correlation between the antioxidative assays and salinity was found to be relatively very low in $H$. fomes and $X$. granatum. Correlation at 0.05 levels was observed for superoxide with soil salinity for $H$. fomes for singlet oxygen with salinity for X. granatum. 


\section{DISCUSSION}

The present work demonstrated the amount of total Tannins, Proanthocyanidin and free radical scavenging ability of three profusely growing and two IUCN red listed mangrove species from five different islands of Indian Sundarbans with varying substrate salinity. Mesophytic complements of these five species were also considered as natural control. Incidence of total tannin showed strong positive correlation among all the three profusely growing taxa i.e. B. gymnorrhiza, E. agallocha and $P$. paludosa along the salinity gradient. There was no significant correlation with $H$. fomes and $X$. granatum. In the later two species the total concentration of tannin increased up to a certain limit (Site IV) along the salinity gradient, beyond which it started to decline. The concentration of tannin also depicted the same trend in these two stressed plants. Tannin or tannic acid is a plant polyphenol (King \& Young 1999) which is considered as a potent antioxidant (Wu et al 2004). Delgado-Andrade et al (2005) reported that tannic acid suppressed the formation of hydroxyl radical.

Proanthocyanidin, widespread in woody plants, are known as condensed proteins. They belong to the earliest detected plant metabolites. They are a group of naturally produced polyphenolic bioflavonoids, explicitly oligomers of polyhydroxy flavan-3-ol units, such as catechin and epicatechin (Porter 1993). Proanthocyanidin possess biological, pharmacological, therapeutic, and chemoprotective properties against ROS and oxidative stress (Mansouri et al 2011, Sharma et al 2004). In the present experiment Proanthocyanidin concentration showed a strong positive correlation with all the five plant species investigated. Although, the correlation was found to be significant at $\mathrm{P} \leq 0.01$ for all the three growing taxa, while significant at $\mathrm{P} \leq 0.05$ for the two stressed plants. Both the amount as well as the increment in Proanthocyanidin concentration was found to be highest in $H$. fomes up to Site IV, after which it declined. In case of $X$ granatum, except of Site IV, steady increment in concentration was registered along the salinity gradient.

Free radicals are molecules or ions having unpaired and unstable electrons and have high affinity towards chemical reaction. In plant system they comprise of Reactive oxygen species, reactive nitrogen species and reactive sulfur Species. ROS can either persist as radicals containing at least one unpaired electron or as reactive non-radical component, both capable of oxidizing other biomolecules. The enhanced productions of different ROS molecules during various stressed conditions inhibit the photosynthetic processes due to absorption of excess PAR which is required during the photosynthetic processes. In such scenario, over reduction of the photosynthetic electron transport chain and amassing of triplet chlorophylls stimulate leakage of electrons energy to oxygen. This ultimately cause damage to macromolecules, including lipids and proteins, resulting in decreased photosynthetic proficiency leading to ill growth (Triantaphylidès etal 2009). 
Electronic excitation of molecular oxygen which results in spin inversion paves the formation of Singlet oxygen $\left({ }^{1} \mathrm{O}_{2}\right)$. This energy is transferred from certain photo excited compounds called photosensitizers. The photosensitizers absorb a photon, producing a short-lived singlet state which eases to a longer-lived $\left(10^{-3} \mathrm{~s}\right)$ triplet state that transmits energy to oxygen, forming singlet oxygen (Knox, Dodge 1985). This is electrophilic and targets compounds with electron-rich functions and profoundly substituted double bonds including unsaturated fatty acids causing lipid peroxidation, histidine, methionine, tryptophan and guanine are oxidized. In the present experiment the percent inhibition of singlet oxygen was found to be in strong positive correlation with salinity for the three growing taxa. But in H. fomes it decreased after Site V, whereas for X. granatum it decreased after Site IV. Site Energized oxygen $\left({ }^{1} \mathrm{O}_{2}\right)$ has major role in photo oxidative stress induced cell death. Triantaphylidès et al (2008) reported that photo oxidative injury to plant leaves is always associated with induced lipid peroxidation $\left({ }^{1} \mathrm{O}_{2}\right)$, irrespective of the initial ROS production.

Superoxide $\left(\mathrm{O}_{2}\right)$ radicals are produced in the mitochondria during auto oxidation of ubiquinone (Cadenas 1989) and in the chloroplast by oxygen reduction at PS I and PS II (Asada 1987). Superoxide $\left(\mathrm{O}_{2}\right)$, Hydrogen Peroxide $\left(\mathrm{H}_{2} \mathrm{O}_{2}\right)$ and hydroxyl radical $(\mathrm{OH})$ are produced by successive univalent reduction of oxygen, where $\mathrm{O}_{2}$ is reduced to form $\left(\mathrm{O}_{2}\right)$, which reduces to $\left(\mathrm{H}_{2} \mathrm{O}_{2}\right)$, further reducing to $\mathrm{OH}$, which ultimately produces $\mathrm{H}_{2} \mathrm{O}$ (Smirnoff 1993). Superoxide radicals are not highly reactive in nature. According to Halliwell \& Gutteridge (1989), damage is more likely from subsequent formation of hydrogen peroxide and hydroxyl radical. Particularly, $\mathrm{OH}$ is one of the most highly reactive ROS. At neutral $\mathrm{pH}$ and ambient temperature, in the presence of appropriate transitional metals, such as iron, $\mathrm{OH}$ can also be produced from $\mathrm{O}_{2}$ and $\mathrm{H}_{2} \mathrm{O}_{2}$ by Fenton reaction (Halliwell \& Gutteridge 1989). OH damages cell by reacting with polyunsaturated fatty acid moieties of cell membrane phospholipids (Khan et al 2012). This radical can react with almost every biological molecule and any constituent cells. Since there is no enzymatic mechanism for elimination of this radical, excess production of $(\mathrm{OH})$ ultimately leads to cell death (Vranova et al 2002). $\mathrm{H}_{2} \mathrm{O}_{2}$ can deactivate some of the calvin cycle enzymes (Charles \& Halliwell 1980). This is a non-radical reactive species, is converted to water by the catalase enzyme. $\mathrm{H}_{2} \mathrm{O}_{2}$ in presence of Chloride ion generates hypochlorous acid [HOCl] (Tirzitis \& Bartos 2010). This molecule is highly oxidative, can react with DNA, persuade DNA-protein interactions and insert chloride to DNA bases (Kulcharyk et al 2001). In this experiment, all the radicals and biologically active molecule found to be in strong relationship with the salinity gradient for the three profusely growing taxa. But the two stressed taxa in every instance exhibited increment up to certain level along the salinity gradient, but in excess salinity (Site IV \& Site V) Site, it started to decrease. 
Nitric oxide generated by nitric oxide synthases is the primary source of RNS. NO is an endogenous maturing and senescence factor in higher plants (Leshem et al 1996). They can react with a variety of intracellular and extracellular targets due to their short lived, readily diffusible nature, resulting in cell death. Peroxynitrite (ONOO) is produced by reaction of superoxide anion radical with NO, which is much more reactive than its precursors. They can initiate lipid peroxidation reactions by removing a hydrogen atom from a polyunsaturated fatty acid and form nitrated lipids (Rubbo et al 1994). They can also induce DNA damage (Dedon et al 2004), protein oxidation and nitration (Ischiropoulos et al 1995), apoptosis and necrosis (Virag et al 2003).

In the present experiment it was evident that B. gymnorrhiza, E. agallocha and P. paludosa, which are growing profusely in the Indian part of the Sundarbans mangrove forest have better radical scavenging mechanism than $H$. fomes and $X$. granatum. $\mathrm{R}^{2}$ values which defines the fitness of curve also showed the same trend. Excess ROS scavenging is an important aspect for successful adaptability of any plant in the Sundarbans' present day elevated saline environment. This result is in accord with the earlier works (Dasgupta et al 2012, 14) where the polyphenol level and antioxidant enzyme level for the three growing taxa had showed strong positive correlation with increasing salinity, unlike the two stressed members. The cumulative effect of all these factors might be responsible for the current lean existence of $H$. fomes and $X$. granatum in Indian Sundarbans. These findings would be relevant marks for selection of comparatively more adapted plant taxa in abiotic stressed condition in relation to occurrence of secondary metabolites and efficiency in radical scavenging ability.

\section{CONCLUSION}

All the three species growing profusely, namely B. gymnorrhiza, E. agallocha and P. paludosa showed higher level of secondary metabolites concentration, which increased gradually along the salinity gradient. Whereas the two lean species, $H$. fomes and $X$. granatum showed weaker response towards higher salinity in term of radical scavenging ability. This phenomenon can be attributed towards their inferior adaptability in present day's high salt concentration in Indian Sundarbans region, which ultimately may have resulted in their precarious existence status.

\section{ACKNOWLEDMENT}

The authors would like to convey their sincere regards to the Director, Sundarbans Biosphere Reserve and Chief Principal Conservator of Forest and Wildlife, Government of West Bengal, for providing required permission to conduct fieldwork in the Sundarbans Reserved Forest time to time. 


\section{REFERENCES}

ARUOMA, O.I. and B. HALLIWELL. 1987. Action of hypochlorous acid on the antioxidant protective enzymes superoxide dismutase, catalase and glutathione peroxidase. -J. Biochem. 248: 973-976.

ASADA, K. 1987. Production and scavenging of active oxygen in photosynthesis. Photoinhibition. Elsevier Sci. Publishers

BECKMAN, J.S., H. CHEN, H. ISCHIROPULOS and J.P. CROW. 1994. Oxidative chemistry of peroxynitrite. Methods Enzymol. 233: 229-240.

BHATTACHARYA, S. 2005. Reactive oxygen species and oxidative burst: roles in stress, senescence and signal transduction in plant. Curr. Sci. 89: 1113-1121.

DASGUPTA, N., P. NANDY and S. DAS. 2011. Photosynthesis and antioxidative enzyme activities in five Indian mangroves with respect to their adaptability. Acta. Physiol. Plant. 33: 803-810.

DASGUPTA, N., P. NANDY, C. SENGUPTA and S. DAS. 2012. Protein and enzymes regulations towards salt tolerance of some Indian mangroves in relation to adaptation. - Trees Struc. Func. 26: 377-391.

DASGUPTA, N., P. NANDY, C. TIWARI and S. DAS. 2010. Salinity-imposed changes of some isozymes and total leaf protein expression in five mangroves from two different habitats. J. Plant Int. 5: 211-221.

DASGUPTA, N., C. SENGUPTA and S. DAS. 2014. Role of Secondary Metabolites and Radical Scavenging Aptitude for Better Adaptability of Mangroves in Varying Salinity of Sundarbans, India. Ann. Trop. Res. 36: $1-21$.

DEDON, P.C. and R. TANNENBAUM. 2004. Reactive nitrogen species in the chemical biology of inflammation. Acta. Biochim. Biophys. 423: 12-22.

DELGADO-ANDRADE, C., J.A. RUFIÁN-HENARES and F.J. MORALES. 2005. Assessing the antioxidant activity of melanoidins from coffee brews by different antioxidant methods.J. Agri. Food. Chem. 53: 7832-7836.

DOGANLAR, Z.B., K. DEMIR, H. BASAK and I. GUL. 2010. Effects of salt stress on on pigment and total soluble protein contents of the three different tomato cultivars. Afr.J. Agri. Res. 5: 2056-2065.

ELIZABETH, K. and M.N.A. RAO. 1990. Oxygen radical scavenging activity of curcumin. Int.J. Pharmaceut. 58: 237-240.

EUROPÉENNE COMMISSION. 2000. procédures de prisesen charge de cereals par les organismesd'interventionainsique les methodesd'analyses pour la determination de la qualité. J. Officielcommunautéseur. 824: 20.

FAO.: FOOD AND AGRICULTURAL ORGANIZATION, UNITED NATIONS (FAO). 2007. The World's Mangroves 1980 - 2005. FAO Forestry Paper 153, FAO, Rome.

FAO.: Food and agriculture organization of the United Nations statistical databases, 2010. http://faostat.fao.org/ 
FONTANA, M., L. MOSCA and M.A. ROSEI. 2001. Interaction of enkephalines with oxyradicals. Biochem. Pharmacol. 61: 1253-57.

GARRAT, D.C. 1964. The Quantitative Analysis of Drugs - Tokyo, Japan: Chapman and Hall Ltd, pp: 456-458.

GAXIOLA, R.A., R. RAO, A. SHERMAN, P. GRISAFI, S.L. ALPER and G.R. FINK. 1999. The Arabidopsis thaliana proton transporters, AtNhx1and Avp1, can function in cation detoxification in yeast. Proc. Natl. Acad. Sci. USA 96: $1480-1485$.

GHOSH, A., S. SCHMIDT, T. FICKERT and M. NÜSSER. 2015. The Indian Sundarban mangrove forests: history, utilization, conservation strategies and local perception. Diversity 7:149-169.

GIRI, C., E. OCHIENG, L.L. TIESZEN, Z. ZHU, A. SINGH, T. LOVELAND, J. MASEK and N.C. DUKE. 2011. Status and distribution of mangrove forests of the world using earth observation satellite data. Global Ecol. Biogeogr. 20: 154-159.

GRATAO, P.L., A. POLLE, P.J. LEA and R.A. AZEVEDO. 2005. Making the life of heavy metal stressed plants a little easier. Funct. Plant Biol. 32: 481494.

HALLIWELL, B. and J.M.C. GUTTERIDGE. 1989. Free radicals, ageing and disease. Free radicals in boil. Med. 2: 446-493.

HUDA-FAUJAN, N., A. NORIHAM, A.S. NORRAKIAH and A.S. BABJI. 2009. Antioxidant activity of plants methanolic extracts containing phenolic compounds. Afr.J. Biotechnol. 8: 484-489.

IMLAY, J.A. 2003. Pathways of oxidative damage. Ann. Rev. Microbiol. 57: 395-408.

ISCHIROPOULOS, H. and A.B. AL-MEHDI. 1995. Peroxynitrite-mediated oxidative protein modifications. FEBS Lett. 164: 279-282.

KHAN, R.A., M.R. KHAN, S. SAHREEN and M. AHMED. 2012. Evaluation of phenolic contents and antioxidant activity of various solvent extracts of Sonchus asper (L.) Hill. Chem. Central J. 6: 1.

KING, A. and G. YOUNG. 1999. Characteristics and occurrence of phenolic phytochemicals. J.Am. Diet. Assoc. 99: 213-218.

KULCHARYK, P.A. and J.W. HEINECKE. 2001. Hypochlorous acid produced by the myeloperoxidase system of human phagocytes induces covalent cross-links between DNA and protein. Biochem. 40:3648-3656.

LASHEM Y.Y. 1996. Nitric oxide in biological systems. Plant Growth. Regul. 18: $155-159$.

LONG, L.H., P.J. EVANS, and B. HALLIWELL. 1999. Hydrogen peroxide in human urine: implications for antioxidant defense and redox regulation. Biochem. Biophys. Res. Commun. 262: 605-609.

MAHAJAN, S. and N. TUTEJA. 2005. Cold, salinity and drought stresses: An overview.Arch. Biochem. Biophy. 444: 139-158.

MANSOURI, E., M. PANAHI, M.A. GHAFFARI and A. GHORBANI. 2011. Effects of grape seed proanthocyanidin extract on oxidative stress induced by diabetes in ratkidney. Iran Biomed.J. 15: 100-106. 
MAROIS, D.E. and W.J. MITSCH. 2015. Coastal protection from tsunamis and cyclones provided by mangrove wetlands-a review. Int. J. Biodiv. Sc, Eco.Ser. Manag. 11: 71-83.

MILLER, G., N. SUZUKI, L. RIZHSKY,A. HEGIE, S. KOUSSEVITZKY and R. MITTLER. 2007. Double mutants deficient in cytosolic and thylakoid ascorbate peroxidase reveal a complex mode of interaction between reactive oxygen species, plant development, and response to abiotic stresses. Plant Physiol. 144: 1777-1785.

NAKASHIMA, K., K. YAMAGUCHI-SHINOZAKI and K. SHINOZAKI. 2014. The transcriptional regulatory network in the drought response and its crosstalk in abiotic stress responses including drought, cold, and heat. Abiotic Stress: Mol. Gen. Genom. 25.

NANDY, P., S. DAS, M. GHOSE and R. SPOONER-HART. 2007. Effects of salinity on photosynthesis, leaf anatomy, ion accumulation and photosynthetic nitrogen use efficiency in five Indian mangroves. Wetl. Ecol. Manag. 15: 347-357.

OYAIZU, M. 1986. Studies on products of browning reactions: antioxidant activities of products of browning reaction prepared from glucoseamine.Jap.J. Nutr. 44: 307-315.

PARANI, M., M. LAKSHMI, B. ZEIGENHAGEN, M. FLADUNG, P. SENTHILKUMAR and A. PARIDA. 2000. Molecular phylogeny of mangroves VII. PCR-RFLP of trnS - pbsC and rbcL gene regions in 24 mangrove and mangrove associate species. Theor. App. Genet. 100: 454-460.

PARIDA, A.K., A.B. DAS and P. MOHANTY. 2004. Investigations on the antioxidative defense responses to $\mathrm{NaCl}$ stress in a mangrove, Bruguiera parviflora: Differential regulations of isoforms of some antioxidative enzymes. Plant Growth Regulat. 42: 213-226.

PEDRAZA-CHAVERRI', J., D. BARRERA, P.D. MALDONADO, Y.I. CHIRINO, N.A. MACI'AS-RUVALCABA, O.N. MEDINA-CAMPOS, L. CASTRO, M. SALCEDO and R. HERNÁNDEZ-PANDO. 2004. S-allylmercaptocysteine scavenges hydroxyl radical and singlet oxygen in vitro and attenuates gentamicin induced oxidative and nitrosative stress and renal damage in vivo. BMC Clin. Pharmacol. 4: 5.

Porter, L.J. 1993. The Flavonoids. In: Harborne J.B., (Ed.), Advances in Research Since 1986. - London: Chapman, Hall. 23-55.

RUBBO, H., R. RADI, M. TRUJILLO, R. TELLERI, B. KALYANARAMAN, S. BARNES, M. KIRK, B.A. FREEMAN. 1994. Nitric oxide regulation of superoxide and peroxynitrite-dependent lipid peroxidation. Formation of novel nitrogen-containing oxidized lipid derivatives. $J$. Biol. Chem. 269: 26066-26075.

SANCHEZ, M.G., J.M. PALMA, J.A. OCAMPO, I.G. ROMERA and E. ARANDA. 2014. Arbuscular mycorrhizal fungi alleviate oxidative stress induced by ADOR and enhance antioxidant responses of tomato plants. J. Plant Physio. 171: 421-428. 
SHARMA, G., A.K. TYAGI, R.P. SINGH, D.C. CHAN and R. AGARWAL. 2004. Synergistic anti-cancer effects of grape seed extract and conventional cytotoxic agent doxorubicin against human breast carcinoma cells. Breast Cancer Res. Treat. 85: 1-12.

SHARMA, P., A.B. JHA, R.S. DUBEY and M. PESSARAKLI. 2012. Reactive oxygen species, oxidative damage, and antioxidative defense mechanism in plants under stressful conditions.J. Bot. 2012: 1-26.

SHI, H., M. ISHITANI, C. KIM, J.K. ZHU. 2000. The Arabidopsis thaliana salt tolerance gene SOS1 encodes a putative Na?/H? antiporter. Proc. Nat. Acad.Sci. USA. 97: 6896-6901.

SPALDING, M.D., A.L. MCIVOR, M.W. BECK, E.W. KOCH, I. MÖLLER, D.J. REED, P. RUBINOFF, T. SPENCER, T.J. TOLHURST, T.V. WAMSLEY and B.K. WESENBEECK. 2014. Coastal ecosystems: a critical element of risk reduction. Conser. Lett. 7: 293-301.

SUN, B., J.M. RICARDO-DA-SILVA and I. SPRANGER. 1998. Critical factors of vanillin assay for catechins and proanthocyanidins. J. of Agri. Food. Chem. 46: 4267-4274.

THE IUCN RED LIST OF THREATENED SPECIES. Version 2016-1, 2016. $<$ www.iucnredlist.org>

TIRZITIS, G. and G. BARTOSZ. 2010. Determination of antiradical and antioxidant activity: basic principles and new insights. Acta Biochim. Pol. 57: 139-142.

TRIANTAPHYLIDÈS, C. and M. HAVAUX. 2009. Singlet oxygen in plants: production, detoxification and signaling. Trends plant sci. 14: 219-228.

TRIANTAPHYLIDÈS, C., M. KRISCHKE, F.A. HOEBERICHTS, B. KSAS, G. GRESSER, M. HAVAUX, F. VAN BREUSEGEM and M.J. MUELLER. 2008. Singlet oxygen is the major reactive oxygen species involved in photooxidative damage to plants. Plant physiol. 148: 960-968.

VIRÁG, L., E. SZABO, P. GERGELY and C. SZABO. 2003. Peroxynitriteinduced cytotoxicity: mechanism and opportunities for intervention. Toxicol. Lett. 140: 113-124.

VRANOVA, E., S. ATICHARTPONGKUL, R. VILLARROEL, M.V. MONTAGU, D. INZE and W.V. CAMP. 2002. Comprehensive analysis of gene expression in Nicotiana tabacum leaves acclimated to oxidative stress. Proc. Natl.Acad. Sci. U.S.A. 99: 870-875.

$\mathrm{Wu}, \mathrm{X} ., \mathrm{Gu}$, L., Prior, R.L., McKay, S.: Characterization of anthocyanins and proanthocyanidins in some cultivars of Ribes, Aronia, and Sambucus and their antioxidant capacity. - J. Agr. Food Chem. 52: 7846-7856, 2004. 